症例

\author{
大胸筋内に発症した平滑筋肉腫の 1 例 \\ 岐北厚生病院外科, 岐皁大学医学部生命細胞医科学講座腫瘍病理学* \\ 田中善宏涉谷智顕山本悟 \\ 竹内賢渡辺敦久野壽也*
}

平滑筋肉腫は，皮成や皮下軟部組織に発症することはきわめて稀である. 今回われわ れは，右大胸筋内に発症した平滑筋肉腫の 1 例を経験したので文献的考察を加え報告す る. 症例は70歳男性. 主訴は右前胸部の皮下腫瘤。右前胸部に $20 \times 5 \mathrm{~mm}$ 大の皮下腫瘤 を認めた。皮闾の変色は認めず, 自発痛・圧痛も認めなかった。過去 7 年間に 3 回の右 大胸笳原発の平滑筋肉腫を切除されていたが, 今回 3 回目の前胸部での局所再発の診断 のもとに, 腫瘤広範囲切除を行った. 免疫組織化学検查にて平滑筋肉腫局所再発と診断 された。過去 7 年間にわたり，他蔵器の腫瘍性病変は認めず，右大胸筋内の血管平滑筋 原発の平滑筋肉腫の局所再発と考えられた，術後 4 力月を経過している現在, 再発・転 移徴候は認めていないか，今後さらに笽重な経過観察を要するものと考える。

索引用語：平滑筋肉腫，大胸筋，局所再発

はじめに

平滑筋肉腫は，おもに子宮・泌尿生殖器・消化管な どの内缄器官にみられる悪性腫瘍であり, 皮用や皮下 軟部組織に発症するものは稀である。.また，皮肉・皮 下組織より発症する肉腫の $2 \sim 3 \%$ \%占めるにすぎな いとされている”. 今回われわれは, 大胸筋に原発した 平滑筋肉腫の 1 例を経験したので文献的考察を加え報 告する.

症例

患者：70歳, 男性.

主訴：右前胸部腫瘤。

家族歴：特記すべきことなし。

既往歴：平成 8 年 8 月に $2 \mathrm{~cm}$ 大の右前胸部腫瘵に 気づく. 平成 9 年 2 月に当院外科受診し, 同腫㿔に対 し, 皮下良性腫瘍の診断のもと局所麻酔下に腫㿔摘出 術施行され, 右大胸筋原発の平滑筇肉腫と診断された。 その時, 追加切除を锄めるも拒否され, 外来経過観察 となっていた。同年 11 月に $1.5 \mathrm{~cm}$ 大の腫瘤を局所大胸 筋内に認め, 局所再発の診断で全身麻酔下での広範囲 切除術を勧めるも，全身麻酔下の手術を拒否され，局

2004年11月 $\times$ 日受付 2005 年 2 月21日採用

〈所属施設住所〉

テ501-2105 山県市高富1187-3
所麻酔下で腫瘤から $1 \mathrm{~cm}$ 離し, 周囲の大胸筋を含め 腫熘切除術施行された. 平成10年 5 月に再び局所大胸 筋内に $1 \mathrm{~cm}$ 大の腫瘤として, 局所再々発を認め, 全身 麻酔下に腫瘍辺縁から $2 \mathrm{~cm}$ の距離をとり, 広範囲切 除施行された。

現病歴：平成16年 6 月に右前胸部の手術創部の皮下 腫瘤に気づき来院した。

入院時現症：身長 $163 \mathrm{~cm}$, 体重 $53 \mathrm{~kg}$. 血圧 130/65 $\mathrm{mmHg}$, 脈拍 $78 /$ 分整. 体温 36.9 度. 結膜に貧血・黄疸 を認めず．右前胸部に $20 \times 5 \mathrm{~mm}$ 大の皮下腫瘤を認め た．皮埔の変色は認めず, 自発痛・圧痛も認めなかっ た.

入院時血液生化学検査：特に異常值を認めなかつ

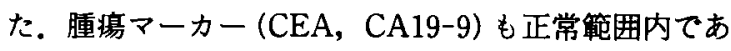
った

胸部単純 $\mathbf{X}$ 線写真：肺野・緃郭に腫瘤影は認めなか った。

前胸部超音波検查所見：皮闻直下に辺緑平滑明瞭て 内部やゃ不均一な $20 \times 5 \mathrm{~mm}$ 大の low echoic mass を 認めた（図 1 )。

胸腹部 CT 検査：右前胸壁に造影効果を受ける腫瘤 を認めた（図 2 ）。肺・肝に腫瘤影は認めなかった。

骨シンチ検査：骨転移を示唆する異常集積像は認め なかった。 


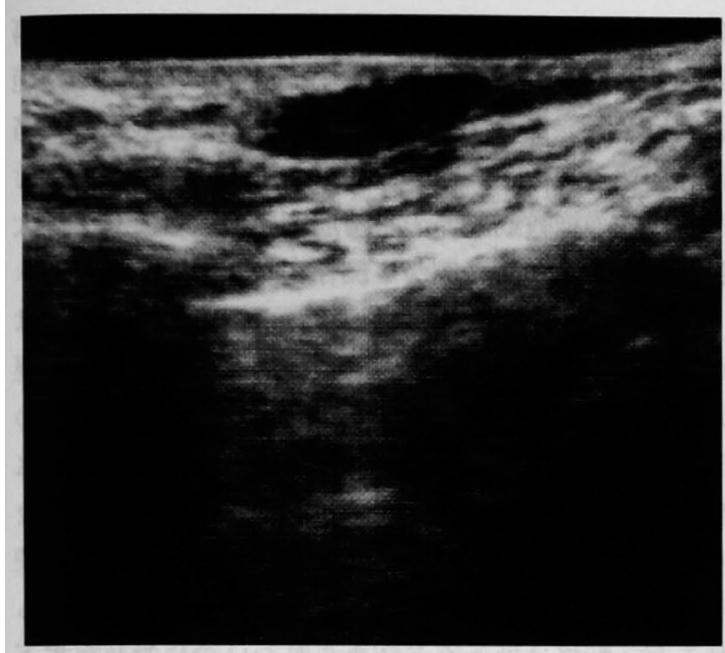

図 1 入院時超音波検查：皮府直下にて, 右大胸筋に接

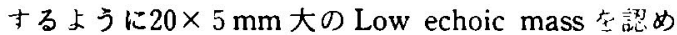
た.

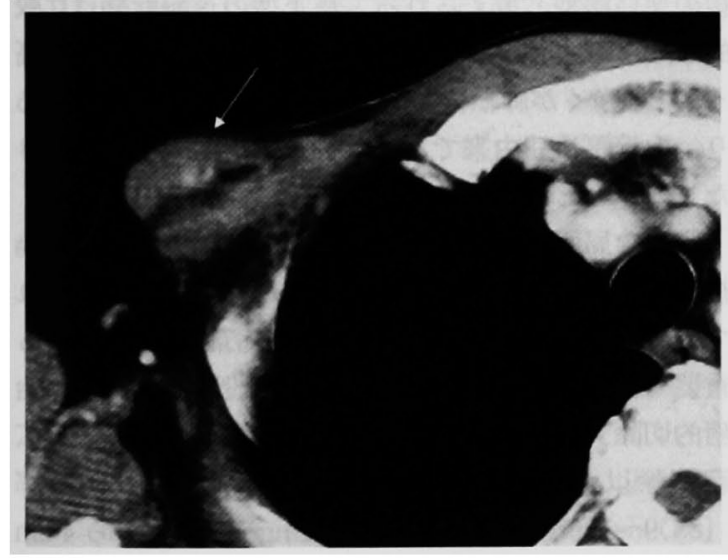

図 2 入院時胸部 CT 検査：大胸筋に接するように右前 胸壁に若干の造影効果を伴う腫瘤影を認めた。リンパ 節の腫脹は認めなかった。

上部・下部消化管内視鏡検査：腫湯性病変を認めな かった

以上の所見より，前胸部平滑筋肉腫局所再発の診断 で全身麻酔下に広範囲切除術を施行することとした。

手術所見：腫瘤辺縁加ら $2 \mathrm{~cm}$ 離し皮㲊も切除し， 腫瘤加ら $5 \mathrm{~cm}$ 離し, 大胸筋ごと合併切除（広範囲切 除）した，術中迅速病理検查にて切除端の浸潤像のな いことを確認した。

切除標本：腫瘍は弾性硬で，被膜に被われており， 周囲との境界は明瞭であった。割面は灰白黄色で，結 節状の発育を示していた。

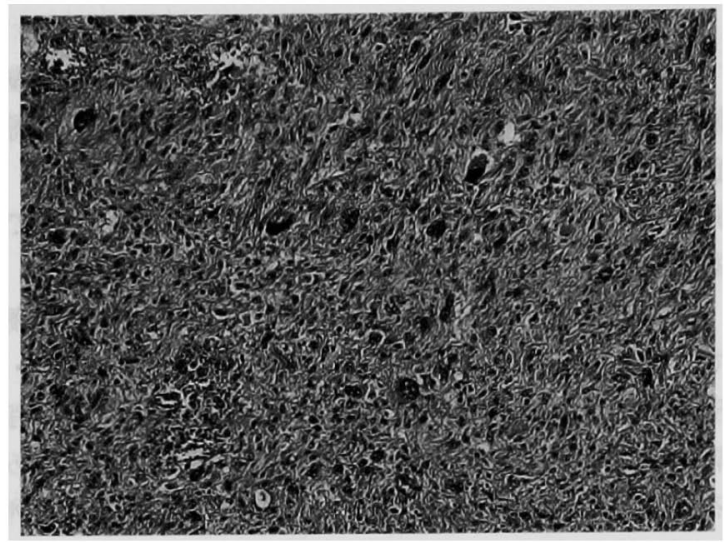

図 3 病理組織学的所見：紡鍾形の腫惶細胞を基調に, 分裂の目立つ多形成に富んた腫瘍細胞の横紋筋組織へ の浸潤を認めた (HE 染色100倍)。

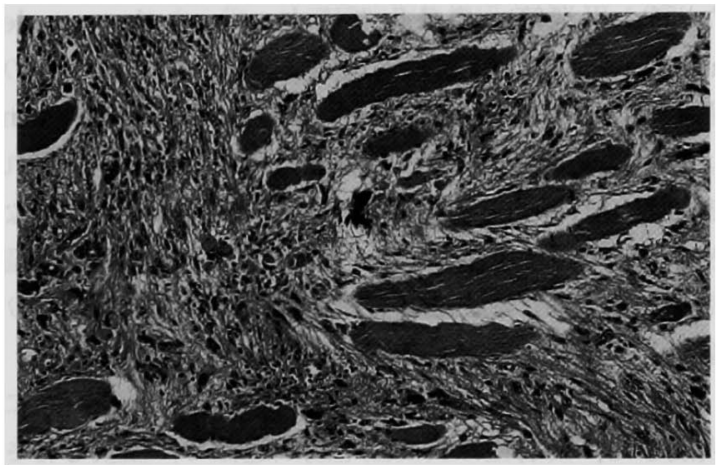

囯 4 初回手術時の病理組織学的所見：横紋筋（正常） を巻き込むように增殖する, 核腫大し多核も伴う spindle cells 認めた (HE 染色100倍).

病理組織学的所見：皮下組織から筋層に分け入り， 置換するように大小不同な核を有する楕円〜紡錘形の 異型細胞が浸潤性增殖していた（図 3). Mitosisも見 られた.PTAH 染色では胞体は淡紫色に染まるが横紋 は認めなかった．特殊免疫染色で Smooth muscle actin, Vimentinに対する抗体は陽性で, Keratin, NSE, S-100蛋白では陰性であった。以上の所見より平 滑筋肉腫の局所再発と診断された。なお，初回手術時 の腫凗の病理学的検査所見では，大胸筋筋膜下に存在 した腫瘍が，横紋筋（正常）を巻き込むように増殖す る核腫大した spindle cellsを認めた（図4）。

術後経過：術後の経過は良好で，7日目に退院した。 現在手術後 4 力月を経過しているが，再発徵候は認め ていない。 


\section{考察}

Enzinger らは平滑筋肉腫を発生部位別に，1) 後腹 膜腔および腹部平滑筋肉腫，2）皮㙏および皮下平滑 筋肉腫，3）血管起源性平滑筋肉腫に 3 型に大別し， 発症頻度は 1）が92.40\%を占め, 他 2つは極めて稀で あるとしだ。

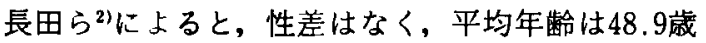
で，発生部位は下肢・体幹部に多くみられた，皮成・ 皮下に発生する本腫瘍の多くは, 単発性で弾性硬・有 痛性て，皮居は正常色あるいは出血を認めることもあ $3^{3)}$. 大きさは直径 $2 \mathrm{~cm}$ 以上が多く, $5 \mathrm{~cm}$ 以上の症例 はより悪性度が高いとの報告もある゙。

近年, 特殊免疫染色により, 平滑筋肉腫を鑑別診断 上で問題となる悪性線維性組織球腫や線維肉腫などの 他の紡錘形線維肉腫と鑑別することが可能になっ た(1)(6). 平滑筋への分化を示す $\alpha$-smooth muscle actin や筋原性腫瑒細胞に発現のみられる desminの 陽性所見が得られう。ただし， $\alpha$-smooth muscle actin は筋線維芽細胞や筋上皮細胞においても発現がみられ るため, Myoglobin, S-100蛋白, facter VIIIや CD-34な どの陰性所見も重要である”。 また, 鍍銀染色で腫瘍細 胞を取り囲むようにして好銀線維が交錯する「箱入り 像」と呼ばれる所見が特徴的である。

病理組織学的には, Fields ら”は皮周型と，皮下型に 大別した，皮周型は真皮立毛筋が起源て，被膜を有さ ないことが多く，周囲との境界が不明瞕で，血管成分 に乏しい，腫瘍細胞が真皮上層に限局し渦巻状・索状 の配列（fascicular pattern）がみられ，ときに立毛筋 の形状に類似した構造を認める。皮下型は，皮下脂肪 織の血管壁平滑筋を起源とし，被膜を有することが多 く，周囲との境界が明暸で，血管成分に富む像 (vascular pattern) を示寸.

電子䫓微鏡検查所見では，立毛筋由来の場合，腫焬 細胞に接してミエリン䩗を破っていない軸索すなわち 神経終末があり，その myofilament は actinのみから なる。一方血管平滑筋では, myofilament の太さは単 一ではなく, actin と myosinからなる。

しかし腫瘍が真皮から皮下組織にかけて存在する例 もあり，立毛筋由来か血管平滑筋由来かを爰密に区別 することは困難である゙!。

自験例では初回手術時に大胸筋の筋膜下に存在し, 被膜に被われ周囲との境界も明瞙であることから大胸 筋内の血管平滑筋由来の可能性が高い．また初回手術 以来 7 年以上が経過しているが，その間全身検索にて
前胸部以外に腫瘍性病変を認めておらず，原発性腫瘍 と考えられた. Medline, 医学中央雑誌にて検索した範 囲内（会議録を除く）では，大胸筋に発症した平滑筋 肉腫の報告はなく，非常に稀なケースであるといえた。 な掞，他の横紋筋原発の平滑筋肉腫の報告として，大 腿筋肉内からの原発例が 2 例存在した ${ }^{9110}$.

岩瀬ら ${ }^{11} は ，$ 腫瘤を自覚してから初診までの期間は 平均 2 年 2 力月とし, 皮㖇平滑筋肉腫は発達速度の遅 い悪性腫瘍と考えられる。

転移・再発に関しては，再発しても腫瘍が真皮内に 限局していれば転移しにくいが，皮下組織に存在また は浸潤すれば，再発および転移を生じやすい，Fields ${ }^{7)}$ によれば,皮后型の約 $1 / 3$ の症例に局所再発が認めら れるが，転移はほとんど認められないのに対し，皮下 型では約半数に局所再発が認められ，さらに約 $1 / 3$ の 症例に転移が認められた。再発を繰り返すにつれて腫 瘍の浸潤度は深くなると考えられ，皮下型は，より予 後の悪い病型と考えられる。皮下型の遠隔転移は比較 的早期より生じ，リンパ行性よりも血行性の転移が高 く，その多くが肺転移であるて12).病変がより深部にあ り，血管平滑筋由来であることから，血行性転移をき たしやすいと思われる。

高率な局所再発に関し，その原因は腫瘍の表面に偽 被膜が形成され，不完全に摘出されるためと考えられ ている ${ }^{13)}$. 早期診断と外科的広範囲切除が治療上最も 重要であり，日整会で定義された 4 段階の切除縁（治 疮的切除 - 広範切除 - 辺緑部切除 - 腫瘍内切除) の広 範切除以上であれば，良好な局所コントロール率 (83.9 100\%)を得られる ${ }^{14)}$. King は, 腫瘍から $4 \mathrm{~cm}$ 以上離して切除した場合，有意に再発率が低かったと している(5).

単純な腫瘍切除または病巣内局所切除の局所コント ロール率は不良 $(8.5 \%)$ て, 追加切除を必要とす る $^{16) 17}$. 追加広範切除にて, 広範切除以上の切除縁であ れば，初回広範切除と同程度の局所コントロール率を 得られると考えられており ${ }^{18)}$ ，初回手術が腫瘍切除に 終わった自験例のようなケースでは早期の追加広範囲 切除をしていれば良好な局所コントロールを得られた 可能性はある. なお追加切除の切除縁が広範切除以上 であるためには, 初回手術の㗪痕, 出血巣の外側での 切除が必須条件で, 追加広範切除は, 初回切除後早期 の瘷痕・血腫の境界が明瞭なうちに行うことが望まし い. 早期追加切除群と, 再発時追加切除群を比べた場 合, 再発例は予後不良となる傾向がある ${ }^{291211}$. 
自験例での二度目の再発時の手術では，睡瘤辺緑か ら2 cm 離し，接する大胸筋も合併切除した小， 3 回目 の再発をみた。再発を繰り返すうち，より深部への浸 潤が明らかになり，複数回の手術による疫痕形成も相 まって，深部方向への広範囲切除の境界を確保するの が困難であったためと考えている。

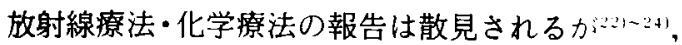
いまだ確立された投与方法はない。一般的には，Vincristine - Cyclophosphamide - Adriamycin • Actinomycin-D を組み合わせた併用療法が行われて いる. Pinedo らによれば CYVADIC 療法に対する有 奻率は，200。化学療法に対する感受性は低い,2.5.

\section{結語}

大胸筋に発症し，局所再発を繰り返した平滑筋肉腫 の 1 例を報告した。今後さらに厳重な経過観察を要す るものと考える。

\section{文献}

1) Enzinger FM. Weiss SW : Leiomyosarcoma ; in Soft Tissue Tumors. $2^{\text {nd }}$, ed, C. V. Musby Co, St. Louis, 1995, p491-505

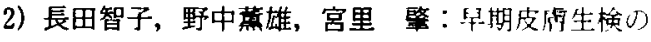
必要性を痛感させられた皮病平滑箭肉腫の 1 例。 西日皮 $66: 474-478,2004$

3）山本純照, 桶口昌則, 岡崎愛子：皮店平滑筋肉腫 の 1 例. 皮店 $40: 388-393,1998$

4）澤泉雅之, 丸山 優: 表在性平滑筋肉腫. 形成外 科 $33: 189-194 ， 1990$

5) Huvos AG: Bone Tumors: Diagnosis, Treatment, and Prognosis, $2^{\text {nd }}$ ed., WB Saunders Co., Philadelphia, 1991, p756-762

6) Young CL, Wold LE, McLeod RA, et al: Primary leiomyosarcoma of bone. Orthopedics $11: 615-618,1988$

7) Fields JP, Helwig EB : Leiomyosarcoma of the skin and subcut aneous tissue. Cancer $47: 156$ $-169,1981$

8）金澤浩之，南本俊之，安田聖人他：表在性平滑筋 肉腫の治療経験一本邦報告例の検討一，日形会誌 22:294-3(11), 2002

9）中川由美, 篠崎哲也, 有田 党他：大眼に発生し た平滑筋肉腫の 1 例. 関東整災外会誌 $30: 143-$ 145,1999

10）間野正平，竹内仁司：大腿筋内原発平滑筋肉腫の 1 例. 岡山外科病理研会誌 $27: 116-117,1990$
11）岩瀨悦子，飯田真由美，長谷川順一他：皮店平滑 筋肉腫の 1 例。皮间 $33: 580-585,1991$

12）姥山勇二：四肢の軟部肉腫の治療について. 形成 外科 $40: 43-54,1997$

13) Clark RL:Clinical aspects of soft-tissue tumors. Arch surg 71:859-870, 1957

14）伊崎寿之, 花岡英㜊，矢部啓夫他：軟部肉腫の治 療成績. 整形外科 $48: 793-799,1997$

15) King RM, Pairolero PC, Trastek VF, et al: Primary chest wall tumors. Factors affecting survival. Ann Thorac Surg 41:597-601, 1986

16) Norman LC, Edward HS, Patrick JK : Synovial sacoma; an analysis of 134 tumors. Cancer 18 : $613-627,1965$

17）站机䏚于，車地祐子，勝俣道夫他：leiomyosarcoma 01 例. 日皮病病理組織研会誌 $2: 29-$ 31,1986

18）久保田光昭, 福嶋 稔, 菅原 忍他: 追加広範切 除を行った腹壁平滑筋肉腫の 1 例。整形外科 $51: 1673-1675,2000$

19）鬼頭正志, 梅田 添: 追加広範切除と再発後広範 囲切除を行った軟部肉腫の検討.臨整外 $31: 903$ -908, 1996

201)村田博昭, 楠崎克之, 平田正純他：悪性軟部腫場 における追加広範切除の有用性. 中部整災誌 $41: 71-72,1998$

21）北野慎治, 土屋弘行, 毛利良彦他：熹性軟部腫場 に対する追加手術の治療成績. 中部整災誌 41 ： 73-74, 1998

22) Gordon MS, Hajdu SI, Bains MS : Soft tissue sarcomas of the chest wall. J Thorac Cardiovasc Surg $101: 843-854,1991$

23）富樫賢一, 矢沢正知, 佐藤良智 : 胸壁平滑筋肉腫 の 1 手術症例. 日胸外会誌 $41 ： 1562-1566,1993$

24) Marshall DG, Bains M: Massive leiomyosarcoma of the chest wall in a young child. Jornal of Pediatric Surgery 15:666-669, 1980

25) Pinedo HM, Bramwell VHC, Mouridsen HT, et al:CIVADIC in advanced soft tissue sar. coma: A randomized study comparing two scheduies. A study of the EORTC Soft Tisuue and Bone Sarcoma Group. Cancer 53 : 18251832. 1984 


\title{
A CASE OF LEIOMYOSARCOMA ARISING IN THE PECTRAL MUSCLE
}

\author{
Yoshihiro TANAKA, Chiken SHIBUYA, Satoru YAMAMOTO, \\ Makoto TAKEUCHI, Atsushi WATANABE and Toshiya KUNO* \\ Department of Surgery, Gihoku Kosei Hospital \\ -Department of Pathology, Gifu University
}

\begin{abstract}
Among tumors of the soft parts, leiomyosarcoma rarely occurs, especially that primary arising in the pectral muscle. We report a 70-year-old man with leiomyosarcoma who had operated on three times for leiomyosarcoma arising in the pectral muscle originating from the smooth muscle of blood vessels. $\mathrm{He}$ noticed a subcutaneous nodule with no tenderness in the right precordia. A heterogeneous mass shadow, measuring $20 \times 5 \mathrm{~mm}$ in diameter, was detected in the right chest wall by US scanning. There were no color changes on the skin. An operation was performed with a diagnosis of locally recurred leiomyosarcoma. The operative procedure was wide spread surgical excision including the surrounded pectral muscle. Histological examination showed spindle-shaped tumor cells in a fascicular pattern in a whirlpool style with round-oval nucleus. Immunohistological analysis showed that the tumor cells were positive for both smooth muscle actin and vimentin but negative for keratin and NSE. Accordingly we diagnosed this case as local recurrence of leimyosaroma. Postoperative course was uneventful. No recurrence or metastasis has occurred as of 4 months after the operation. The patient is closely followed on ambulant basis. Some bibliographical comments are also presented.
\end{abstract}

